Argonne National Laboratory, the 'big science' community does not escape scotfree: about $\$ 60$ million has been deleted from the basic energy science research budget, which includes much support of high-energy physics experimentation.

Research into superconductivity, covering traditional 'low-temperature' materials as well as the new superconductors, benefits to the tune of $\$ 95$ million, and a project to collaborate with industry on the exploitation of hightemperature superconductors is planned for Los Alamos National Laboratory.

A sum of $\$ 19$ million has been set aside for work on the human genome project, in collaboration with NIH.

\section{Department of Defense}

SDI retains high priority with a 40 per cent increase requested, well above the 2.8 per cent rise scheduled for total defence spending, and the 2.0 per cent for nonSDI research programmes. But the projected $\$ 4,950$-million expenditure is still almost $\$ 2,000$ million below that planned by the administration a year ago and will require cuts in some SDI projects.

The trend towards research on high velocity interceptor rockets and other kinetic-energy weapons at the expense of research on exotic particle-beam weapons is likely to intensify as the administration looks for early results.

The fact that more tests will be necessary is sure to bring the administration back into conflict with Congress over the interpretation of the Anti-Ballistic Missile Treaty.

In the non-SDI research programme, the 'Orient Express' National Aerospace Plane is budgeted for a large increase in a joint project with NASA. Another collaboration with NASA is the Advanced Launch System, an expendable rocket for heavy payloads.

A set of basic research programmes in electronics is also emphasized, including a very-high-speed integrated circuit project and support for Sematech, the private microchip research consortium.

Other Agencies

The administration request for the US Geological Survey (USGS) reflects reductions for "numerous lower priority program activities". The areas being cut back include regional aquifer analysis, nuclear waste and coal hydrology and work on coastal erosion. Extra money is requested for advanced cartoraphic systems.

The National Oceanographic and Atmospheric Administration continues its fall from financial favour in the White House budget. Marooned by bureaucratic structure in the Department of Commerce, it will be cut in all research and operational areas, except environmental satellite date, which receive an increase mostly for the purchase of replacement weather satellites.

\title{
Army renews controversial plans for biological warfare laboratory
}

Boston

THE debate over the US Army's plans to build a controversial high-containment facility to study biological warfare agents was rekindled with the recent release of a draft environmental impact statement attesting to the safety of the venture.

The Army's lengthy report concludes that the facility, designed for aerosol testing and experimentation with deadly and highly infectious biological warfare agents, "would have no reasonably fore-

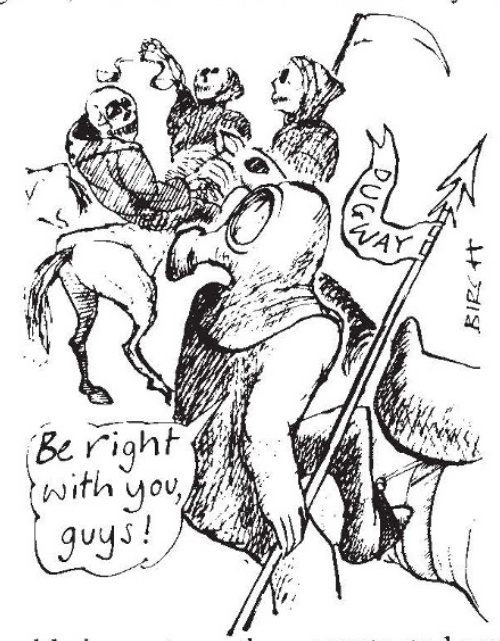

seeable impacts on the unprotected populace or the environment". The multimillion-dollar facility is at the Army's Dugway Proving Ground in Utah.

The Army's impact statement does acknowledge a potential hazard from "accidental occupational exposure" if an infected worker were to leave the facility, but claims that sufficient steps have been taken to avoid such a prospect in the design of the facility and in a programme to immunize workers against the diseases they will study. A two-month comment period now follows the issuing of the draft report, after which a final impact statement will be released. But critics of the Dugway facility are already complaining.

The proposed "maximum-containment" facility at Dugway has been a cause of controversy since its conception. The Army's current environmental impact statement emerged only after a court ruling in 1985 in response to a successful lawsuit brought by the Foundation on Economic Trends, led by Jeremy Rifkin.

Rifkin calls the latest report "grossly inadequate", claiming that the reviewers failed to consider seriously the possibilities of sabotage and terrorism, the proposed use of non-lethal simulants instead of actual pathogens, or the possibility of siting the facility elsewhere. Rifkin threatens to sue again unless these and other criticisms are dealt with in the final report.

Barbara Rosenberg, a research scientist at the Sloan Kettering Institute in New York and also an outspoken critic of the facility, and other scientists, including Nobel laureate David Baltimore, have argued against the construction of the facility at Dugway.

Very few known warfare agents require the highest biosafety level (BL-4) containment that the Army proposes for the Dugway facility. In fact, the Army claims that only research requiring the lower BL-3 rating will be conducted at Dugway, but it wants the capability to conduct the more dangerous research.

Seth Shulman
NIH conclude misconduct investigation

\section{Washington}

AN investigation by the National Institutes of Health (NIH) has concluded that there were "serious misrepresentations" in two published papers on the $\mathrm{T}$-cell-activating substance interleukin-4A (IL-4A), and has recommended that the senior author of the paper, Claudio Milanese, be excluded from receiving any further money from NIH.

Milanese was a postdoctoral fellow in the laboratory of Ellis Reinherz at the DanaFarber Cancer Institute in Boston. In October 1986, Reinherz became aware that some of the data provided by Milanese had been fabricated (see Nature 324, 193; 1986). He contacted NIH about the irregularities, and retracted two papers containing the fradulent data (Science 231, 1118; 1986 by Milanese, Neil E. Richardson and Reinherz and $J$. exp. Med. 163, 1583; 1986 by Milanese, Robert E. Siciliano, Reinhold
Schmidt, Jerome Ritz, Richardson and Reinherz). Two other papers in the press were withdrawn. An investigation by Dana-Farber and Harvard Medical School concluded that, in addition to inventing data, Milanese had supplied fraudulent materials to others, and was guilty of "tidying" data to achieve better-looking results.

NIH have now accepted the conclusions of the Dana-Farber investigation. Although the main blame is laid on Milanese, the investigation noted that Reinherz's extensive research commitments "raised troubling questions about the supervision of junior staff in the laboratory." Harvard Medical School and Dana-Farber have agreed to form a committee to monitor Reinherz's laboratories. NIH praise Reinherz and Dana-Farber for investigating this incident and promptly informing the scientific community. 